\title{
The Influence of Organizational Culture, Competence and Self-Awareness on Performance of Employees in Dinas Kebudayaan dan Pariwisata Provinsi Jawa Timur
}

\author{
Naisya Nur Karimah ${ }^{1}$, Siti Mujanah ${ }^{2}$ \\ 1,2Faculty of Economics and Business, University of 17 August 1945 Surabaya \\ e-mail: naisyann13@gmail.com ${ }^{1}$ sitimujanah@untag-sby.ac.id ${ }^{2}$
}

\begin{tabular}{|c|c|}
\hline ARTICLE INFO & ABSTRACT \\
\hline $\begin{array}{l}\text { Keywords: Organizational } \\
\text { Culture, Competence, Self } \\
\text { Awareness and Employee } \\
\text { Performance. }\end{array}$ & $\begin{array}{l}\text { This study aims to determine the effect of organizational culture, } \\
\text { competence and self-awareness on the performance of the } \\
\text { employees of the Culture and Tourism Office of East Java } \\
\text { Province. Respondents in this study amounted to } 55 \text { employees } \\
\text { through the distribution of questionnaires with sampling } \\
\text { techniques using saturated samples. This study uses quantitative } \\
\text { methods. The data analysis technique used is multiple linear } \\
\text { regression analysis. Data processing in this study using IBM SPSS } \\
\text { Statistics } 23 \text {. The results of this study indicate that organizational } \\
\text { culture has a significant effect on employee performance, } \\
\text { competence has a significant effect on employee performance, } \\
\text { self awareness has no significant effect on employee } \\
\text { performance. Organizational culture, competence and self- } \\
\text { awareness simultaneously have a significant effect on employee } \\
\text { performance with a significance value of } 0.000<0.05 \text {. The results } \\
\text { of the coefficient of determination show a value of } 65.7 \% \text { which } \\
\text { means that all independent variables (organizational culture, } \\
\text { competence and self-awareness) affect the Employee } \\
\text { Performance variable, while the remaining } 34.3 \% \text { is influenced by } \\
\text { other variables not examined in this study. From this explanation, } \\
\text { the authors suggest evaluating and developing organizational } \\
\text { culture, competence and self-awareness in order to improve } \\
\text { employee performance. }\end{array}$ \\
\hline
\end{tabular}

\section{Introduction}

The current of globalization that is currently taking place requires everyone to improve the quality of themselves, even to be more effective and efficient in what they do. In the face of change, caution is needed to be able to adapt to the changes that are happening now. In order to be able to compete with other human resources (HR) to be better, especially in advancing the organization itself. The organization itself is a container in which there are activities of people working together to achieve certain goals that have been determined together. Organization is also a process of combining work in which individuals or groups must do the work with the necessary talents to perform tasks, providing the best channels for effective and efficient use, systematic, positive and 
most importantly the coordination of efforts. - the effort made. Our society consists of a variety of different organizations, for example: government organizations, religious, social, political, industrial, educational and so on.

Organizations have a fundamental purpose because the organization is basically the basis of common interests. However, from each individual individual coming not only to achieve goals but the organization is formed because of the similarity in nature, personality, value system and belief, meaning that the organization is a work ethic goal that has characteristics, conditions, personality, value system, work ethic beliefs and beliefs. problems and characteristics of the organization. Organizations have a unique nature in carrying out activities, this is because the organization has a culture or culture that is adopted and applies to every individual and organizational activity. A group of people who are in an organization without realizing it in their daily lives when carrying out their activities in an effort to achieve organizational goals, they carry out habits that gradually become a culture. Therefore, the habits that are carried out by members of the organization that are carried out continuously are what shape the behavior of organizational members and produce a culture that distinguishes one organization from another according to its characteristics.

The problem that usually arises from the organization is the lack of cooperation between employees, this is usually due to the lack of implementation of the characteristics of organizational culture properly. Understanding the characteristics of organizational culture is a guideline to control the behavior of members of the organization itself which has functions and benefits that are useful for the organization. The application of organizational culture is an important part so that the tasks can be carried out seriously by everyone who works in the organization so that the work carried out can improve employee performance. According to [2] stated that performance is the result of work achieved by a person based on job requirements. Employee performance in question is the result of performance shown by employees on a job that is their responsibility in the organization. How to measure it by looking at the final results of the work in the form of treatment, skills, facilities and skills related to organizational goals so as to encourage the emergence of disciplined attitudes and service quality from employees.

Culture provides an identity for members of the organization and evokes a commitment to beliefs and values greater than oneself. Although these ideas have become part of the culture itself, it can come wherever the organization is. A cultural organization serves to connect its members so that they know how to interact with one another. Organizational culture is a system of shared values and beliefs that interact with people in an organization, organizational structure, and control systems that produce behavioral norms to achieve common goals [22].

Organizational culture also contains values that must be understood, inspired, and practiced together by all individuals or groups involved in it. The existence of these values will make employees feel comfortable working, have commitment and loyalty and make employees try harder to improve competitive employee performance. implemented. If every organization has a strong culture, it means that all employees have the same perception in achieving organizational goals. This unity of perception is 
based on the shared values that are believed and the norms that are upheld in the pattern of behavior that is adhered to. These values and beliefs will be realized through the daily behavior of employees at work.

In addition to organizational culture, another factor that affects employee performance is competence. In improving employee performance, adequate competence is needed. Competence has a very important role, because in general competence concerns a person's basic ability to do a job [12]. According to Spencer in [12] competence is a characteristic that underlies a person related to the effectiveness of an individual's performance in his work or the basic characteristics of individuals who have a causal or causal relationship with the criteria used as a reference. So far, many government agencies do not have employees with adequate competence, this is evidenced by the low productivity of employees and the difficulty of measuring employee performance. To achieve maximum and satisfactory work results, it is necessary to have competence possessed by an employee in carrying out his work duties so that employee performance can increase.

Employee competence supported by good self-awareness is a form of human resource management activity to create productivity and a conducive environment. With self-awareness, employees will obey and do their job well, not because of coercion. Threats and punishments can only discipline in the short term. In the long term work discipline must grow from within the individual, not because of the demands of the institution alone [4]. According to [7] self-awareness is readiness for environmental events and cognitive events consisting of memories, thoughts, feelings and physical sensations.

A person with good self-awareness can accurately gauge their own moods, feelings, and understand how their feelings affect others, is open to feedback from others on how to continue to improve, and is able to make the right decisions despite uncertainty and uncertainty. pressure [3], [10] and [14]. Self-aware people must understand their own moods and emotions, be critical of information and truly understand themselves.

Based on the phenomena and empirical facts above, the problem of this research can be formulated: Do organizational culture, competence and self-awareness affect the performance of the employees of the Culture and Tourism Office of East Java Province?

\section{Research Methods}

The type of research used is Causal Explanatory. Causal is a variable that affects other variables [6]. Explanatory Research is research that aims to explain the relationship between variables and research phenomena [6]. Thus, Causal Explanatory serves to explain the causal relationship between the independent variable and the dependent variable. The population of this study were all employees of the Department of Culture and Tourism of East Java Province, totaling 55 employees. The method of determining the number of samples is done by using saturated sampling. According to [16], saturated sampling is a sampling technique when all members of the population are used as samples. The number of samples taken from the Department of Culture and Tourism of East Java Province was 55 respondents. Data analysis methods used include Multiple 
Linear Regression Analysis, t-test (partial), F-test(simultaneous), and Determinant Coefficient Analysis to determine the role of organizational culture, competence and self-awareness on employee performance.

\section{Result and Discussion}

Literature review:

a. Organizational culture

According to [22], Organizational Culture is a system of shared values and beliefs that interact with people in an organization, organizational structure, and control systems that produce behavioral norms to achieve common goals. Organizational culture is the beliefs, norms, values, habits, attitudes and behavior of members in an organization or company created by a group of people who serve as common guidelines in carrying out organizational activities in order to solve internal and external problems and become a differentiator between an organization and other organizations.

According to organizational culture is a set of values, principles, traditions, and ways of working that are shared and influence the behavior and actions of organizational members. For this reason, it must be taught to members including new members as a correct way of studying, thinking, and feeling the problems they face. A strong organizational culture can improve employee performance as stated in [21], as well as the results of his research. Which states that organizational culture has a significant effect on employee performance [15].

b. Competence

According to Spencer in [12] competence is a characteristic that underlies a person related to the effectiveness of an individual's performance in his work or the basic characteristics of individuals who have a causal or causal relationship with the criteria used as a reference. Competence is a characteristic related to the effectiveness of performance that makes the person able to fulfill what is required by the job in a company organization.

Individual competence reflects emotional intelligence, which consists of selfawareness, self-confidence, self-control, commitment, integrity, ability to convey to initiate and accept change. Someone who has competence tends to have high performance, this is in accordance with the results of his research [14] which states that a person's competence can increase his performance, as well as the results of his research also shows that competence has a significant influence on the performance obtained [21]. c. Self Awareness

According to [7] Self Awareness is readiness for environmental events and cognitive events consisting of memories, thoughts, feelings and physical sensations. Selfawareness is the ability of a person to know and understand himself including his strengths and weaknesses, encouragement, values, and their impact on others that can guide individuals in making the right decisions and is also a condition for us to work with others effectively [4].

Self Awareness can also show concern for oneself. The influence of Servant Leadership, Self Awareness and Compensation on oneself, readiness to recognize oneself for what is being done, and understanding of the environment around us. 
Self-awareness is important for employees because it can have a significant effect on employee engagement [13], this shows that increasing employee engagement can be done by providing support to employees in increasing elf awareness of employees and that if self-awareness increased, the auditor's performance would also increase.

d. Employee Performance

[2] According to states that performance is the result of work achieved by a person based on job requirements. Performance can be referred to as the result of a process or work. Therefore, every employee is required to have competence, namely the expertise or ability to do the work that is his responsibility or entrusted. Every application of a task or job there is an activity to process or replace input (input) into an output (output) that has added value as a product or result of work.

Result:

Before further analysis of the data, the validity and reliability tests are carried out, and the results shows that the validity test of each 1 item of question on the variables of Organizational Culture (X1), Competence (X2), Self Awareness (X3) and Employee Performance $(Y)$ indicate that the value of $r$ count is greater than $r$ table, so that every 1 item of question on each variable is declared valid. Meanwhile, the results of reliability testing that was carried out using Cronback Alpha analysis showed the values for each of the variables Organizational Culture (X1), Competence (X2), Self Awareness (X3) and Employee Performance (Y) showed a number greater than 0.6 so that it can be concluded that all research variables are declared reliable.

The classical assumption test was also carried out consisted of the normality test, heteroscedasticity test and multicollinearity test, and the results were as follows:

a. Normality test

Normality test in this study is used to meet the requirements in the use of parametric statistics, namely the use of multiple regression analysis, which is to ensure that the data to be analyzed is normally distributed. The results of the analysis of the Normality Test can be seen in Figure 1.

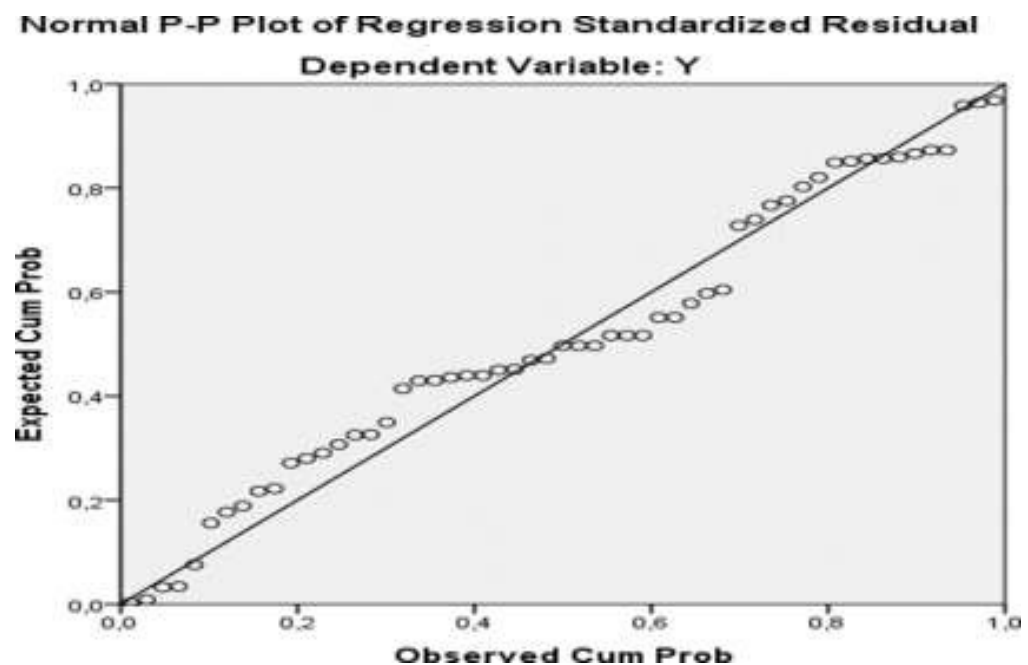

Figure 1. Normal P-P Plot 
Figure 1 shows the normal P-P plot, it can be seen that the points spread around the line and follow the diagonal line. This indicates that the residual data is normally distributed.

\section{b. Heteroscedasticity Test}

Heteroscedasticity test is used to determine whether or not there is a deviation from the classical assumption of heteroscedasticity, namely the existence of an inequality of variance from the residuals for all observations in the regression model. The heteroscedasticity test aims to test whether in the linear regression model there is an inequality of variance from the residual of one observation to another observation.

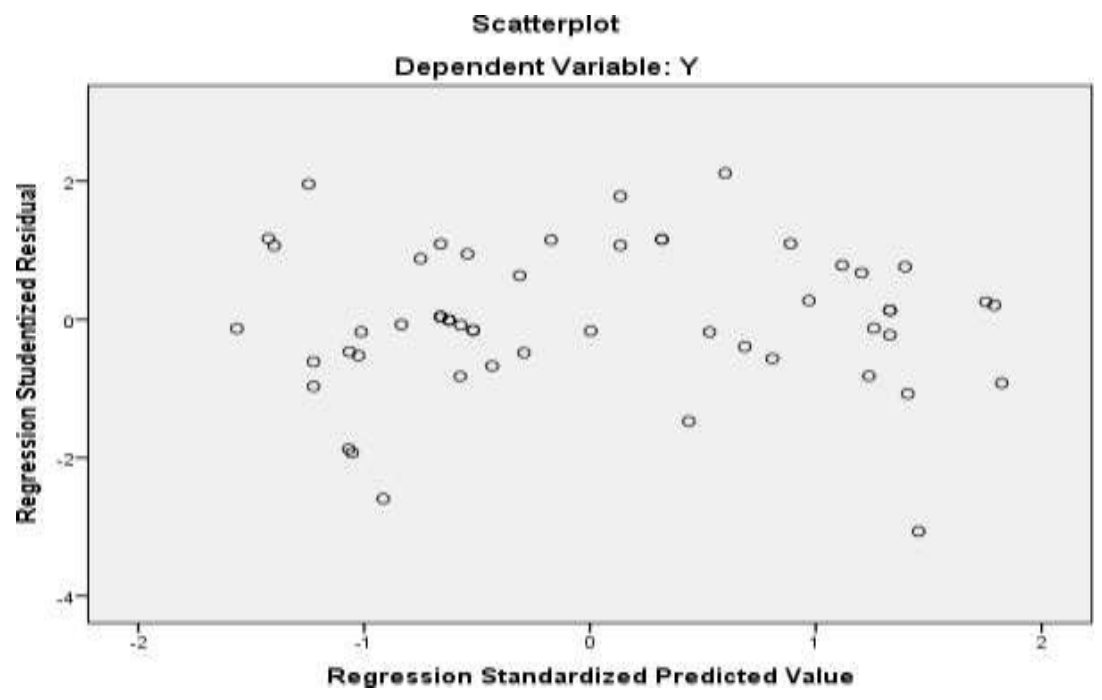

Figure 2. Heteroskedastisitas Test

c. Multicollinearity Test

The multicollinearity test is used for requirements in using regression analysis, this test is carried out to ascertain whether in a regression model there is intercorrelation or collinearity between independent variables, while the results of this collinearity test can be seen in table 1 .

Table 1 Multicollinearity Test Results

\begin{tabular}{lrr}
\hline \multicolumn{1}{c}{ Model } & \multicolumn{2}{c}{ Collinearity Statistics } \\
& Tolerance & VIF \\
\hline (Constant) & 0.421 & 2.373 \\
Organizational Culture & 0.333 & 3.005 \\
Competence & 0.598 & 1.673 \\
\hline
\end{tabular}

Table 1 shows that the results of the Multicollinearity test can be seen that the value of the recruitment variable, workload and facilities has a tolerance value $>0.1$ and a VIF value $<10$ so it can be concluded that the independent variable does not occur multicollinearity because the three variables are smaller than 10 so there is no there is multicollinearity between independent variables in the regression model.

d. Multiple Linear Regression Analysis 
Multiple linear regression analysis is used to determine the effect of a variable on other variables and if the variable is more than 2 (two). The results of the regression analysis are then compiled into a regression equation.

Tabel 2 Hasil Analisis Regresi Linear Berganda

\begin{tabular}{|c|c|c|c|c|c|c|}
\hline & \multirow{2}{*}{ Model } & \multicolumn{2}{|c|}{$\begin{array}{l}\text { Unstandardized } \\
\text { Coefficients }\end{array}$} & \multirow{2}{*}{$\begin{array}{c}\begin{array}{c}\text { Standardized } \\
\text { Coefficients }\end{array} \\
\text { Beta }\end{array}$} & \multirow{2}{*}{$\mathbf{T}$} & \multirow{2}{*}{ Sig. } \\
\hline & & B & $\begin{array}{l}\text { Std. } \\
\text { Error }\end{array}$ & & & \\
\hline \multirow[t]{4}{*}{1} & (Constant) & ,736 & 4,652 & & 158 & 875 \\
\hline & Organizational Culture & 417 & 167 & 316 & 2,500 & 016 \\
\hline & Competence & ,476 & ,152 & ,446 & 3,138 & 003 \\
\hline & Self Awareness & 143 & 143 & 140 & 1,321 & 192 \\
\hline
\end{tabular}

Table 2 shows the results of the regression analysis, and if it is entered into the multiple linear regression equation it will be as follows:

$$
\mathrm{Y}=0.736+0.417 \mathrm{X} 1+0.476 \mathrm{X} 2+0.143 \mathrm{X} 3+\mathrm{e}
$$

Based on the linear equation model mentioned above, it can be interpreted as follows: The value of $\mathrm{b} 1$ shows a positive number of 0.417 its mean that the organizational culture has an effect on the employee performance, while the value of $b 2$ shows a positive number of 0.476 meaning that there is an effect between the competency and the employee performance. Likewise, the result of self awareness a value of 0,143 , this mean that self awareness has an efffect on the employee performance.

\section{e. Coefficient of Determination (r2)}

The coefficient of determination is used to describe how much variation is explained in the model. Based on the value of R2, it can be seen the level of significance or the suitability of the relationship between the independent variables and the dependent variable in linear regression.

Table 3 Results of the Coefficient of Determination (r2)

\begin{tabular}{cccccc}
\hline Model & $\mathbf{R}$ & $\mathbf{R}$ Square & $\begin{array}{c}\text { Adjusted R } \\
\text { Square }\end{array}$ & $\begin{array}{c}\text { Std. Error of the } \\
\text { Estimate }\end{array}$ & $\begin{array}{c}\text { Durbin- } \\
\text { Watson }\end{array}$ \\
\hline 1 &, $810^{\mathrm{a}}$ &, 657 &, 636 & 2,899 & 2,515 \\
\hline
\end{tabular}

Table 3 shows the results of the determination test (R2) with a coefficient of determination of 0.657 or $(65.7 \%)$. This shows that the influence of the independent variables consisting of organizational culture, competence and self-awareness. Can explain the dependent variable, namely employee performance of $65.7 \%$ while the rest is explained by other variables that are not included in this study.

f. T-test (Partial)

The t-test is used to partially test the hypothesis, namely to test the effect of each independent variable individually on the dependent variable. This test can be done by looking at the significance value, if the Sig value is below 0.05 then the hypothesis is 
accepted, while if the sig value shows a number above 0.05 then the hypothesis is rejected.

Table 4. T-Test Results (Partial)

\begin{tabular}{|c|c|c|c|c|c|c|}
\hline & \multirow[t]{2}{*}{ Model } & \multicolumn{2}{|c|}{$\begin{array}{l}\text { Unstandardized } \\
\text { Coefficients }\end{array}$} & \multirow{2}{*}{$\begin{array}{c}\begin{array}{c}\text { Standardized } \\
\text { Coefficients }\end{array} \\
\text { Beta } \\
\end{array}$} & \multirow[t]{2}{*}{$\mathrm{T}$} & \multirow[t]{2}{*}{ Sig. } \\
\hline & & B & Std. Error & & & \\
\hline \multirow{4}{*}{1} & (Constant) & 736 & 4,652 & & 158 & 875 \\
\hline & $\mathrm{X} 1$ & ,417 & 167 & ,316 & 2,500 & ,016 \\
\hline & $\mathrm{X} 2$ & ,476 & 152 & ,446 & 3,138 & ,003 \\
\hline & X3 & 143, & 109, & 140 & 1,321 & 192, \\
\hline
\end{tabular}

The results of the t-test analysis in table 4 can be seen and interpreted as follows: 1. The Influence of Organizational Culture on Employee Performance

Based on the results of the $\mathrm{t}$-test in table 4 , the Tcount value for the organizational culture variable is 2.500 and the probability value is 0.016 . When compared between the results of the probability value < significance level, this states that the hypothesis is accepted. Thus, it can be concluded that partially the organizational culture variable has a positive and significant effect on employee performance.

2. The Effect of Competence on Employee Performance

Based on the results of the analysis with the $t$ test in table 4 , the Tcount value for the Competence variable is 3.138 and the probability value is 0.003 . When compared between the results of the probability value < significance level, this means that $\mathrm{H} 0$ is rejected. So it can be concluded that partially the competence variable has a positive and significant effect on employee performance.

3. The Effect of Self Awareness on Employee Performance

Based on the results of the t-test in table 4, the Tcount value for the self-awareness variable is 1.321 and the probability value is 0.192 . When compared between the results of the probability value $>$ the level of significance, this means that $\mathrm{H} 0$ is accepted. So it can be concluded that partially positive self-awareness variable has no effect and is not significant on employee performance.

\section{g. F Test (Simultaneous)}

The $\mathrm{F}$ test is used to test the effect of the independent variables simultaneously (simultaneously) on the dependent variable. Thus the F test was conducted to see the effect of all independent variables together on the dependent variable. The test results with the F-Test can be seen in table 5 .

Table 5. F Test Results (Simultaneous)

\begin{tabular}{llrrrrr}
\hline Model & $\begin{array}{r}\text { Sum of } \\
\text { Squares }\end{array}$ & Df & $\begin{array}{c}\text { Mean } \\
\text { Square }\end{array}$ & F & Sig. \\
\hline 1 & Regression & 819,170 & 3 & 273,057 & 32,502 &, $000^{\mathrm{b}}$ \\
& Residual & 428,467 & 51 & 8,401 & & \\
& Total & 1247,636 & 54 & & & \\
\hline
\end{tabular}


Table 5 shows the results of the F-test analysis calculations, from the F-test results indicate that the F-test value is 32,502 with a significant value of 0.000 , so it can be said that the significance value shows a number less than 0.05 , it can be concluded that the organizational culture variable, competence and self- awareness simultaneously have a positive and significant effect on employee performance.

Discussion:

\section{a. The Influence of Organizational Culture on Employee Performance}

Based on the results of the IBM SPSS 23 t-test output in the table above, the Tcount value for the organizational culture variable is 2.500 and the probability value is 0.016 . When compared between the results of the probability value of the significance level, this indicates that the hypothesis in this study is accepted. So it can be concluded that partially the organizational culture variable has a positive and significant effect on employee performance. This research is reinforced by the results of previous research conducted by [15] which states that organizational culture has a positive and significant effect on employee performance. Likewise, the results of [21] state that organizational culture has a significant effect on employee performance.

b. The Influence of Competence on Employee Performance

Based on the results of the t-test in the table above, the Tcount value for the Workload variable is 3.138 and the probability value is 0.003 . When compared between the results of the probability value < significance level, this indicates that the hypothesis in this study is accepted. So it can be concluded that partially the competence variable has a positive and significant effect on employee performance. This research is strengthened by the results of previous research conducted by which states that competence has a positive and significant effect on employee performance. Likewise, the results of research [14] which states that a person's competence can improve his performance, as well as the results of his research by[21] also shows that competence has a significant influence on the performance obtained.

c. The Effect of Self Awareness on Employee Performance

Based on the results of the t-test analysis, the Tcount value for the selfawareness variable is 1.321 and the probability value is 0.192 . When compared between the results of the probability value $>$ the level of significance, this indicates that the hypothesis in this study was rejected. So it can be concluded that partially the selfawareness variable has an effect and is not significant on employee performance. The results of this study do not support the results of research conducted, which states that improving employee performance can be done by providing support to employees in increasing elf awareness, which states that if self awareness increases the auditor's performance will also increase.

\section{Conclusion}

Based on the results of the study, the conclusion in this research is that organizational culture and competence have a significant effect on employee performance at the Culture and Tourism Office of East Java Province, but self awareness 
has no significant effect on employee performance. Thus the implications of the results of this study indicate that the leadership of government agencies can support employees by creating a strong culture and increasing the competence of their employees so as to improve their performance.

Recommendation: Based on the assessment of the results of this research, the leadership needs to optimize indicators of organizational culture and competence by giving awards to the skills, work performance, or competencies possessed by employees so that they can improve employee performance for further research. others related to improving employee performance.

\section{References}

[1] Amirullah. 2015. Pengantar Manajemen. Jakarta : Mitra Wacana Media

[2] Bangun, Wilson. 2012. "Manajemen Sumber Daya Manusia". Jakarta: Erlangga.

[3] Candraningrat, C. (2017). Pengambilan Keputusan sebagai Wirausaha Muda dan Faktor Eksternal yang Mempengaruhinya di Institut Bisnis dan Informatika Stikom Surabaya. Business and Finance Journal, 2(1), 1-14.

[4] Candraningrat, C. (2019). Business Plan" a Simple Strategy To Grow A Remarkable Business".

[5] Candraningrat, C. (2020). The Effect Of Entrepreneurship Education On Interests Of Entrepreneurship Through Self Awareness In Students In Surabaya. Jurnal Ekonomi dan Manajemen: jmm17, 7(01).

[6] Cooper \& Schindler. 2011. Business Research Methods, 11thed. New York: McGraw-Hill Companies Inc.

[7] Daliana. (2016). Deskripsi Self Awareness Dan Kemampuan Penalaran Matematis Siswa Kelas VII SMP Muhammadiyah Sokaraja. Thesis Universitas Muhammadiyah Purwokerto

[8] Edison, Emron. Yohny anwar, Imas komariyah. (2016). Manajemen Sumber Daya Manusia. Bandung: Alfabeta.

[9] Hamali, Arif Yusuf. 2016. Pemahaman Sumber Daya Manusia. Yogyakarta: CAPS.

[10] Karya, D. F.,, Rasyid, R. A. \& Candraningrat, C. The Effect Of Work Interfere Family And Family Interfere Work On Commitments Through Satisfaction And Motivation. Exspektra: Jurnal Bisnis dan Manajemen. Vol 5 (1)

[11] Karya, D. F., Rasyid, R. A. \& Candraningrat, C. (2021, May). Entrepreneurial Commitments: Study at Woman Entrepreneurs in Surabaya. In 2nd International Conference on Business and Management of Technology (ICONBMT 2020) (pp. 31-37). Atlantis Press.

[12] Moeheriono, 2014, Pengukuran Kinerja Berbasis Kompetensi Edisi Revisi, Jakarta: PT Raja Grafindo Persada

[13] Mujanah, S., \& Aini, S. N. (2020). Transformational Leadership, Kondisi Kerja Dan Budaya Organisasi Pengaruhnya Terhadap Kinerja Karyawan. Business and Finance Journal, 5(2), 155-164.

[14] Mujanah, Siti, Tri Ratnawati, and Amiartuti Kusmaningtyas. "The effect of competence, emotional quotient, and financial quotient on the business performance of small and medium enterprises in Surabaya, Indonesia." 
Proceeding 16th International Symposium on Management (INSYMA 2019), Hal. 2019.

[15] Permana, Yohanes Satria Wahyu. dan Mujanah, Siti. 2019 Analisis Pengaruh Budaya Organisasi, Dukungan Organisasional dan Sistem Penilaian Kinerja Terhadap Kinerja Karyawan Melalui Organizational Citizenship Behavior D I Bank Jatim. Global. Vol. 02, No. 02

[16] Rachman, Taufiqur. Mujanah, Siti. Dan Susanti Nanis. 2021 Servant Leadership, Self Awareness dan Kompensasi Pengaruhnya Terhadap Employee Engagement dan Kinerja Karyawan pada Puskesmas Tanjungbumi Madura. Media Mahardika 19 (2), 361-371

[17] Rivai, Veithzal dan Sagala, Ella Jauvani. 2009. Manajemen Sumber Daya Manusia untuk Perusahaan dari Teori ke Praktik. Jakarta: PT Raja Grafindo

[18] Sedarmayanti. 2017. Sumber Daya Manusia dan Produktivitas Kerja. Bandung: CV Mandar Maju

[19] Sugiyono. 2016. Metode Penelitian Kuantitatif, Kualitatif dan R\&D. Bandung: PT Alfabet.

[20] Sutrisno, Edy. 2010. Manajemen Sumer Daya Manusia. Jakarta : Kencana Prenada Media Group

[21] Sumantri, Brahmasari, and Siti Mujanah. "The effect of individual characteristics, competence and quality of work life on work motivation, intention to leave and employee performance outsoursing manufacturing company in East Java Province." Archives of Business Research 5.5 (2017).

[22] Tika, Moh. Pabundu. 2010. Budaya Organisasi Dan Peningkatan Kinerja Peruahaan. Jakarta: Bumi Aksara. 